


\section{THE EFFECT OF HEGEMONIC POWER ON EXECUTIVE COMPENSATION}

By

Aaliya Qudsiya Fayyaz

B.A (Hons.), Queen's University, 1996

A Project Submitted in Partial Fulfilment of the Requirements for the Degree of

\section{MASTER OF BUSINESS ADMINISTRATION}

in the Graduate Academic Unit of Administration

Supervisor: $\quad$ Professor B. Sharma, Ph.D., Industrial Relations

Examining Board: Dr, H. Bansal, Ph.D., Marketing, Chair

Dr. S. Kabadi, Ph,D., Management Science

Dr, E. Otuteye, Ph.D., Finance

The University of New Brunswick

May, 1998

(C) Aaliya Qudsiya Fayyaz, 1998 
National Library

of Canada

Acquisitions and Bibliographic Services

395 Wellington Street Ottawa ON K1A ON4 Canada
Bibliothèque nationale

du Canada

Acquisitions et

services bibliographiques

395, rue Wellington

Ottawa ON K1A ON4

Canada
The author has granted a nonexclusive licence allowing the National Library of Canada to reproduce, loan, distribute or sell copies of this thesis in microform, paper or electronic formats.

The author retains ownership of the copyright in this thesis. Neither the thesis nor substantial extracts from it may be printed or otherwise reproduced without the author's permission.
L'auteur a accordé une licence non exclusive permettant à la Bibliothèque nationale du Canada de reproduire, prêter, distribuer ou vendre des copies de cette thèse sous la forme de microfiche/film, de reproduction sur papier ou sur format électronique.

L'auteur conserve la propriété du droit d'auteur qui protège cette thèse. $\mathrm{Ni}$ la thèse ni des extraits substantiels de celle-ci ne doivent être imprimés ou autrement reproduits sans son autorisation. 


\begin{abstract}
To date, almost all empirical investigations of CEO compensation have focused on economic determinants. Variables included among the economic determinants are firm size, firm revenues, firm assets, or firm income/loss. However, a significant percentage of variations in CEO compensation have still remained unexplained.

This paper will adopt a well-known theory from the realm of International Relations-the Hegemonic Stability Theory. Using this theory to understand CEO behaviour, I develop a hypothesis that hegemonic power of CEOs has a significant influence on compensation determination of CEOs themselves. The main objective of this study was to shed some new light on the determinants of CEO compensation.

The results of this study indicate a limited support for the hegemonic power hypothesis. However, this study has attempted to make a small contribution to the growing body of literature on CEO compensation by bringing in a new crossdisciplinary perspective.
\end{abstract}




\section{ACKNOWLEDGEMENT}

I never thought that a leisurely trip to Fredericton in the summer of 1996 would span over two years of serious academic pursuit. But it did happen, and happened in a way that provided an opportunity to synthesize my undergraduate studies in political science with my business administration studies. This became possible with the help and encouragement of several people inside and outside of academia. From among those who are in academia, I owe a special debt of gratitude to Professor M. Rashid who not only eased the process of entering the department as a degree candidate, but also provided immense help and guidance in devising my program of study.

To Professor B. Sharma, my project supervisor, I am particularly thankful for his time and effort in shaping the project and seeing to it that it is carried through in and a scholastic manner. I have benefited tremendously from his insightful suggestions and comments which, I'm sure, will serve me even beyond the confines of this project.

I also wish to extend my thanks to the examining committee which made valuable observations for refining the project into its present finished form.

To my close friends, I am especially grateful for their support in times of academic pressures. Without their words of encouragement, completion of the MBA program would not have been as smooth as it turned out to be.

I also wish to record my sincerest thanks to $\mathrm{Mr}$. M. Arif and family for their genuine hospitality throughout my stay in Fredericton. In addition, I would like to express my appreciation for Dr. M. Mumtaz Akhter who sacrificed his time and energy in helping me overcome trials and tribulations of the relocation process.

Last but not least, I am deeply indebted to my parents for everything that they have done, and keep doing, for my well-being. Their extraordinary interest and enthusiasm in my academic career, by and large, remains unparalleled. 


\section{TABLE OF CONTENTS}

I Introduction...................................................1

Theories and Hypotheses...................................2

Standard Economic Determinations.........................3

Political Influence and CEO Compensation................8

Hegemonic Stability Theory and CEO Compensation....10

II Empirical Model, Method, and Sources of Data................13

III Empirical Results and Discussion............................16

IV Conclusions...................................................20

References......................................................21

Vitae...................................................................24 


\section{LIST OF TABLES}

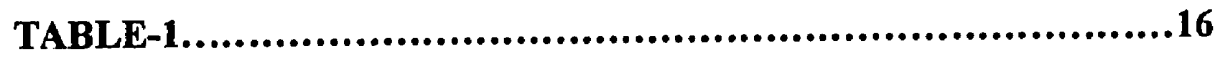

TABLE-2.......................................................16

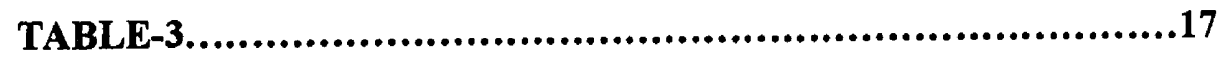




\section{INTRODUCTION}

Executive compensation has attracted the attention of managers, compensation experts, organization theorists, accountants, and economists (O'Reilly III, Main, and Crystal, 1988). Although often phrased in different forms, the central question they frequently ask in relation to executive compensation is "What are the determinants of CEO compensation?" To date, almost all empirical investigations of CEO compensation have focused on economic determinants. Variables included among the economic determinants are firm size, firm revenues, firm assets, or firm income/loss (O'Reilly, Main, and Crystal, 1988; Tosi and Gomez-Mejia, 1989; GomezMejia, Tosi and Hinkin, 1987). However, a significant percentage of variations in CEO compensation has still remained unexplained. Hence economists, in recent attempt to align microeconomic theory with empirical reality, have postulated that executive salary structures can be likened to a series of tournaments or lotteries among contestants (O'Reilly III, Main, and Crystal, 1988).

In addition to these economic determinants, there is some reason to suspect that noneconomic factors may also be important in the determination of executive salaries. Several studies, for example, have shown that power or the form of organizational control used can affect the level and structure of executive compensation (Gomez-Mejia, Tosi, and Hinkin, 1987). To continue with the tradition of looking to other fields of knowledge to explain 
CEO compensation, this paper will adopt a well-known theory from the realm of International Relations--the Hegemonic Stability Theory. Using this theory to understand CEO behaviour, I develop a hypothesis that hegemonic power of CEOs has a significant influence on compensation determination of CEOs themselves. Thus the objective of this research is to examine the effect of hegemonic power on CEO compensation across a sample of Canadian corporations.

This paper is organized into 4 sections. Section one reviews the literature on the determinants of CEO compensation and develops arguments for incorporating hegemonic power as one of the key factors in the determination of CEO compensation. Section two postulates an empirical model of CEO compensation, discusses estimation technique and describes data used for estimation of the model and their sources. Estimated results are presented and discussed in section three. Summary and conclusions are presented in the final section with a brief discussion of their implications for further research.

\section{THEORIES AND HYPOTHESES}

Although often complex in practice, CEO remuneration essentially consists of three components: (1) cash compensation, typically consisting of a salary and bonus; (2) a variety of perquisites and supplementary benefits such as insurance, club memberships, and other noncash rewards; and (3) long- 
term incentives, which may include various forms of stock options and deferred compensation (O'Reilly III, Main and Crystal, 1988). The perks represent a very small fraction of the total compensation package, and the determinants of cash compensation have been established by many theorists. The long-term incentive package scarcely has been studied, even though it may represent a very large amount. A reason for this may be that it is typically difficult to establish the worth of this component since the future value of stock options or performance shares is highly uncertain and difficult to value at the time awarded (Antle and Smith, 1985). A review of this literature is presented next.

\section{Standard Economic Determinants}

A number of studies have explored the relationships between firm, industry, and individual characteristics and CEO compensation (e.g., Ciscel and Carroll, 1980). They find four classes of variables relevant: (1) corporate size, (2) firm performance, (3) industry, and (4) human capital attributes.

There is abundant research linking firm size to CEO compensation (Ehrenberg and Milkovich, 1988; Gomez-Mejia, Tosi, and Hinkin, 1987), and several explanations for this finding have been offered. It may be that the CEO's job in a large firm, typically indexed by sales, assets, or number of employees, is more complex and has more responsibility than in a smaller firm. It may also be that large firms simply have an ability to pay a higher 
level of compensation. Simon (1957) argued that the larger firms have more hierarchical levels and, because firms attempt to insure adequate pay differentials between hierarchical levels, are likely to pay more to CEOs. Agarwal (1981) states that studies of executive compensation have generally emerged as by-products of the development of the theory of large firms. According to this theory, the modern corporation tends to maximize its size rather than profitability as traditionally held. Due to separation of control from ownership, the executives are less constrained to follow the owners' economic goals. They can act instead to serve their own economic selfinterest.

This is also known as agency problem, giving rise to agency theory in economics. According to the agency theory, each firm consists of a principal and an agent. The assumptions of agency theory are that agents are motivated by self-interest, are rational actors, and are risk-averse. Therefore, principals can motivate agents by controlling their incentives. An agency dilemma occurs, however, when a principal is unable to adequately monitor or assess an agent's behaviour. This situation results when the agent's task is less programmable, when accomplishing the task entails risks, or when the goals of the principal and agent are in conflict (Stroh, 1996).

The lack of congruence between the goals of the shareholders, as represented by the board of directors, and executives, and the resulting conflict between the two is discussed at length in the agency theory literature. 
Briefly stated, agency theory deals with the principal-agent relationship. This relationship results from a contract, expressed or implied, in which the agent (the senior executives) undertakes to operate in the best interests of the principal (the board of directors). In return, the principal undertakes to compensate the agent for all reasonable expenses incurred in the course of the execution of the mandate. The principal-agent relationship is fruitful and harmonious when both share the same goals, and when the principal has the capacity to determine that the agent has operated within the terms of the mandate (Kanungo and Mendonca, 1997).

In addition to the lack of goal congruence between shareholders and executives, the other major reason for the conflict, is that the board of directors do not have the same access to information, as executives do. Without such information it becomes difficult for the board to properly evaluate whether executives have performed in the best interests of the shareholders and to reward them accordingly.

In any case, such self-interest would motivate the executives to maximize company size, in part, because "executive salaries appear to be far more closely related to the scale of operation of the firm than to its profitability" (Baumol, 1959). Roberts (1959) has provided an explanation of the empirical relationship between executive compensation and company size in terms of the neo-classical economic theory. He suggests that the marginal productivity of a chief executive varies directly with the size of the 
company managed. Hence the larger the size, the higher the marginal productivity (Agarwal, 1981). By implication then, the chief executives in larger companies would be paid more than those in smaller ones.

Another way to explain this phenomenon is by using the "sales maximization" hypothesis. It states that as firms grow, owners become dispersed and have trouble monitoring management. Therefore, executives pursue their own interests instead of trying to maximize shareholders' wealth (Scott and Tiessen, 1995). By increasing sales, they achieve greater prestige and higher compensation.

Lewellen and Huntsman (1970) came to a conclusion contradicting empirical findings of the earlier researchers. They found a statistically significant positive profit-compensation relationship and no relationship between sales and compensation. This unexpected result touched off a wave of additional studies over the next several years, but no clear resolution of the debate emerged.

A second economic determinant that has been postulated to be related to executive compensation is firm performance. The economic argument here is obvious. Because the CEO is the individual responsible for the overall performance of the organization, rewards should be contingent on this criterion (O'Reilly III, Main, and Crystal, 1988). Although the argument is logical, the evidence for a clear link between performance and rewards is mixed. Stolley (1987), for example, has observed that when a board 
evaluates a chief executive's performance, "there are no rights and no wrongs, only grays." Even more to the point, Gomez-Mejia, Tosi, and Hinkin (1987) have noted, "What is most intriguing in the literature investigating executive compensation is that, after controlling for size, researchers have not found the relationship between CEOs' pay and performance to be as strong or consistent as the classical economic theories would imply." Nevertheless, some studies do show some correlation between changes in executive compensation and performance as indexed by measures such as earnings per share and return on equity (Lewellen and Huntsman, 1970).

Masson (1971) specified stock performance in addition to rather than in place of profit, arguing that maximization of net worth may be a performance criterion partly independent of yearly firm profit. Masson concluded that stock performance was a better predictor of CEO compensation than either sales or profit (Deckop, 1988).

A third economic variable that can be associated with CEO pay levels is industry. Compensation consultants, for instance, have observed that there are industry-wide differences in top-management salaries (O'Reilly III, Main, and Crystal, 1988). Some industries have adopted conventions of paying higher or lower than others, independent of organizational characteristics such as size or performance. 
A final set of economic determinants sometimes postulated to affect productivity in the job and, hence, salary are human capital variables such as education, work experience, and tenure in the company (Hogan and McPheters, 1980). The logic underlying human capital considerations and pay levels is that individuals who have made personal investments in jobrelevant skills and experience should earn a premium. Alternatively, CEOs hired from other firms may also command a premium to take the job as they tend to have more on-the-job training. Although such arguments can be applied to CEO compensation, the empirical evidence is not strong (GomezMejia, Tosi, and Hinkin, 1987). Nevertheless, the length of time an individual has served as a CEO may affect potential compensation, either through human capital factors or ability to manage the compensation-setting process, and should be considered as an independent variable.

In addition to these standard economic determinants, there are also political factors that influence $\mathrm{CEO}$ compensation. A discussion of the role of political influence on CEO compensation follows next.

\section{Political Influence and CEO Compensation}

The literature on organizational politics indicates that attempts to influence important people may be rather consequential (Bloom and Milkovich, 1996). Politics is a fact of organizational life. Every member of the organization is involved in politics, though in varying degrees. 
Management has been defined by some as the art of getting things done through people (Buhler, 1994). Politics is one of the mechanisms that enables the manager to get things done through people.

One can use political theory to better understand the process of CEO compensation determination. For example, one way to look at organizational politics is to see CEO performance dependent upon identifying, fostering, and maximizing strategic alliances with financial institutions, governments, and other key players (Bloom and Milkovich, 1996). This political role is multifaceted--part diplomat, lobbyist, negotiator, sales person, and even figurehead, representing the company at important events (Bloom and Milkovich, 1996).

Another way to view organizational politics is taken by Tosi and his colleagues (Gomez-Mejia, Tosi, and Hinkin, 1987; Tosi and Gomez-Mejia, 1989). Their work focuses on the ability of owners to monitor and control managerial actions. For example, in manager-controlled firms, the company's stock is not owned by a single large stockholders, therefore, managers are able to influence the performance contingency of their pay (Gomez-Mejia, Tosi, and Hinkin, 1995).

Westphal and Zajac (1994) used political theories to explain the adoption of long-term CEO incentive plans that are not put into actual use. For example, the number of board of director members appointed by the CEO may be positively related to the CEO's ability to manipulate his/her 
compensation and that of other senior executives. This depicts managers as willing to manipulate their income through political means.

Building upon the insights coming from the political influence approach, one could extend the notion of political power exerted by CEOs in organizations similar to the power of a hegemon in international relations. The way a dominant state, the hegemon, articulates and enforces rules of interaction, a CEO can exert his/her power to influence and articulate his/her preferences, including higher compensation. Thus an index of hegemonic power should have a significant influence on CEO compensation. What follows is a clarification of and elaboration on this hypothesis.

\section{Hegemonic Stability Theory and CEO Compensation}

The Hegemonic Stability Theory was proposed to analyze international systems. It assumes that the stability of the International System requires a single dominant state to articulate and enforce the rules of interaction among the most important members of the system. And the dominant state is known as the hegemon.

To be a hegemon, a state must have three attributes: (a) the capability to enforce the rules of the system, (b) the will to do so, and (c) a commitment to a system which is perceived as mutually beneficial to the major states. Capability rests upon three attributes: a large, growing economy, dominance 
in a leading technological or economic sector, and political power backed up by projective military power.'

The international system is a collective good which means that it is plagued by a "free-rider" syndrome. Thus, the hegemon must induce or coerce other states to support the system. For example, the US system tries to produce democracy and capitalism, thus it champions human rights and free trade. Other nations will try to enjoy the benefits of these institutions, but will try to avoid paying the costs of producing them. Thus, the US must remain committed to free trade even if its major trading partners erect barriers to trade because the US is the biggest beneficiary of the system.

If an economic power can sufficiently dominate the international economy, it can provide a hegemonic stability which enables other states to cooperate with it and with one another (Hollis and Smith, 1990). This suggests an answer to a question which has troubled international political economists since the early 1970s-- what happens when the hegemon needed for hegemonic stability begins to decline? The answer is that the stability will

THE HISTORICAL RECORD OF HEGEMONIC POWERS IN THE WORLD SYSTEM:

Portugal 1494 to 1580 (end of Italian Wars to Spanish invasion of Portugal). Based on Portugal's dominance in navigation Hegemonic pretender: Spain.

Holland 1580-1688 (1579 Treaty of Ultrecht marks the foundation of the Dutch Republic to William of Orange's artival in England) Based on Dutch control of credit and money. Hegemonic pretender: England.

Britain 1688 to 1792 (Glorious Revolution to Napoleonic Wars) Based on British textiles and command of the High Seas. Hegemonic pretender: France.

Britain 1815 to 1914 (Congress of Vienna to World War I) Based on British industrial supremacy and railroads.

Hegemonic pretender: Germany.

United States 1945 to 1971 (Based on Petroleum and the internal combustion engine.

Hegemonic pretender: the USSR. 
persist in the form of regimes which continue to promote the economic interests of the hegemon (Hollis and Smith, 1990).

The neorealistic version of hegemonic stability theory argues that the state is the key player in the international system and the condition of international regimes mainly depend on the stability of hegemonic state in the international system (Hollis and Smith, 1990). When the hegemonic state has the solid dominance and decides to enforce the neoliberal rules, the international economy will tend to grow and monetary stability and free trade will be prominent. Keohane does not believe that the hegemonic stability theory is valid all the time because international economic regimes during the interwar period were not stable despite high inequality between US and other states. He assumes that the theory works when the hegemonic state is willing to take the leadership role. In this sense, the theory can be applied to the period of 1967-1977 since US actively took the leading role in the international system.

Keohane concludes by saying that the theory of hegemonic stability cannot be used to explain all events because the general trend of hegemon's diminishing power cannot explain changes in all issues. Analyzing various independent variables in different issues is necessary to clarify the causes and consequences. Keohane also remarks that tangible resource models can merely serve as rough approximation and the less tangible resources cannot be neglected. Instead of judging whether the theory of hegemonic stability is 
valid or not, Keohane presents both the validity of theory in international system of 1967-1977 and the weakness of it in trade regime. In any case, the concept of hegemonic power is still a powerful one to analyze cross-national interests in international relations.

One of the ways of looking at a corporate CEO is to compare him/her with a hegemon. Many CEOs have tremendous power over corporate governance. In fact, CEOs are interested in corporate stability and their hegemonic power contributes towards establishing stability in the organization. However, while CEOs are theoretically custodians of corporate interest, they also try to maximize their personal utility. Compensation is one of the important aspects of their utility. Hence they may exert hegemonic power to seek more compensation for themselves. Thus it is plausible to hypothesize that a CEO's hegemonic power will have a statistically significant influence on CEO compensation. The objective of this project is to test this hypothesis so as to provide some empirical content to this argument.

The next section develops an empirical model of CEO compensation together with a discussion of estimation techniques and data sources.

\section{Empirical Model, Method, and Sources of Data.}

The arguments presented above support the contention that hegemonic power of corporate CEOs should have a significant effect on the growth of 
compensation of the CEO. Furthermore, it follows from the review of literature on the determinants of CEO compensation that the growth of revenue, income, and assets (collectively called indicator of corporate financial health) should be related to the growth of CEO compensation. In addition, according to human capital theory, formal education of a CEO should have a significant influence on his/her compensation. Summarizing these arguments, we can posit an empirical model of the determinants of CEO compensation in the following form:

\section{$\mathrm{CEOC}=\mathrm{f}(\mathrm{CFH}, \mathrm{CEOHK}, \mathrm{CEOHP})$}

Assuming a linear relationship, desegregating the $\mathrm{CFH}$ into net income, asset, and revenue, and changing the values of these variables into their growth rates, we can rewrite (1) above as:

$$
\Delta \mathrm{Comp}=\mathrm{a}+\mathrm{b}_{1} \Delta \mathrm{NI}+\mathrm{b}_{2} \Delta \mathrm{Rev}+\mathrm{b}_{3} \Delta \mathrm{Asset}+\mathrm{b}_{4} \mathrm{CEOHK}+\mathrm{b}_{5} \mathrm{HP} 1+\mathrm{b}_{6} \mathrm{HP2}+\mathrm{e}
$$

Where,

$$
\begin{aligned}
& \Delta \text { Comp }=\text { Change in CEO compensation } \\
& \Delta \mathbf{N I}=\text { Change in corporate financial health } \\
& \Delta \mathbf{R e v}=\text { Change in Revenue } \\
& \Delta \text { Asset }=\text { Change in Asset }
\end{aligned}
$$


HP1 = Hegemonic Power as measured by Share ownership by a

CEO

HP2 = Options available to a CEO

CEOHK = Level of CEO's human capital measured by formal education.

e $\quad=$ An error term of the equation

To estimate Equation \#2, data on CEO compensation, net income, revenue, asset, share ownership, options granted to CEOs, and formal education of CEOs are required. Next are discussed sources and computation of these data.

\section{DATA AND SOURCES}

A sample of 75 firms was drawn from The Financial Post Magazine's (November, 1997) annual listing of 200 of the most influential people in corporate Canada. This was in turn based on The Financial Post Magazine's annual ranking of the country's biggest enterprises for the year 1997. This source lists the company's revenue, net income/loss, assets, and total outstanding shares for the years 1995, 1996, and 1997. In addition, the CEO's name, education, compensation, common shares owned, and securities under options granted are listed in the Appendix for the years 1995, 1996, and 1997. Certain information that was not found in the Financial Post Magazine was available either in the company management proxies, 
found in www.sedar.com on the internet, or the FPAnalyst. If the previous methods were unsuccessful, direct contact with the companies was made to acquire missing information. Still there were quite a few missing values for certain variables. After taking out observations with missing values, there were 37 observations with full information in the sample. The compensation variable includes all cash compensation and benefits other than options granted. The index of hegemonic power was created by taking the ratio of number of shares owned by a CEO to the total number of publicly traded shares of the corporation (hereafter HP1). Another measure of this variable was constructed by taking the ratio of number of share granted under option to the total number of shares of the corporation (hereafter HP2). Compensation and other financial variables are expressed in terms of rates of growth in 1996. Information on education includes formal degrees in various disciplines such as business, law and engineering. This variable was transformed into a dummy variable so as to make a distinction across disciplines and to express its impact on the growth of CEO compensation. There were 13 dummy variables with one excluded category.

Table 1 presents data on the highest and the lowest figures for the key variables used in the study for the years 1995 and 1996.

\section{Table 1}

Financial and Compensation Characteristics of Leading Canadian Companies in 1995 and 1996 (the highest and the lowest range) 


\begin{tabular}{|l|l|l|l|l|}
\hline & \multicolumn{2}{|c|}{1995} & \multicolumn{2}{c|}{1996} \\
\hline Particulars & Highest & Lowest & Highest & Lowest \\
\hline Revenue & $\$ 24.6$ bil. & $\$ 135.6$ mil. & $\$ 28.2$ bil. & $\$ 120.7$ mil. \\
\hline Net Income (loss) & $\$ 1.3$ bil. & $\$-1.1$ bil. & $\$ 1.4$ bil. & $\$-278.4$ mil. \\
\hline Assets & & & & \\
\hline Compensation & $\$ 48.9$ bil. & $\$ 189$ mil. & $\$ 53.1$ bil. & $\$ 306$ mil. \\
\hline Share Ownership (\%) & $\$ 3,150,000$ & $\$ 338,545$ & $\$ 8,375,505$ & $\$ 338,173$ \\
\hline Option Eligibility (\%) & 12.25 & .0003 & 73.35 & .000003 \\
\hline
\end{tabular}

\section{Empirical Results and Discussion}

The input data were subjected first to correlation analysis simply to see if there was any problem of multicolinearity. The correlation coefficients are presented in Table 2 .

Table 2

\section{Correlation Coefficients between Variables}

\begin{tabular}{|l|l|l|l|l|l|}
\hline & Asset & Comp & NI & Rev & HP1 \\
\hline Asset & & & & & \\
\hline Comp & .181 & & & & \\
\hline NI & .939 & .199 & & & \\
\hline Rev & .028 & .274 & .112 & & \\
\hline HP1 & -.056 & -.09 & -.091 & .154 & \\
\hline HP2 & -.058 & .124 & -.092 & -.051 & -.052 \\
\hline
\end{tabular}


An examination of the correlation coefficients between pairs of variables makes it clear that growth of incomes and the growth of assets are highly correlated $(r=939)$. Other than between these two variables, there does not seem to be any problem of multicolinearity. The next step in data analysis was to estimate effects of financial, human capital, and hegemonic power variables on the growth of CEO compensation.

Equation \#2 was estimated using the method of the least squares technique. Estimated coefficients of the variables are presented in Table 3.

\section{Table 3}

Regression Results for Growth of Executive Compensation, 1996 (t-statistics in parentheses)

\begin{tabular}{|c|c|c|c|c|c|c|c|c|c|}
\hline & Constant & Rev & $\perp N I$ & HPI & $\mathrm{HP2}$ & Dummy3 & Dummy6 & $R^{2}$ & $F$ \\
\hline$\# 3$ & -19.97 & $\begin{array}{c}.622 \\
(2.358) \\
\end{array}$ & $\begin{array}{c}.006 \\
(1.029)\end{array}$ & $\begin{array}{c}-.134 \\
(-.372)\end{array}$ & $\begin{array}{c}.025 \\
(1.312) \\
\end{array}$ & $\begin{array}{r}-34.736 \\
(-1.98) \\
\end{array}$ & $\begin{array}{l}25.207 \\
(1.48) \\
\end{array}$ & .147 & 2.038 \\
\hline$\# 4$ & -20.43 & $\begin{array}{c}.609 \\
(2.636) \\
\end{array}$ & $\begin{array}{c}.006 \\
(1.092)\end{array}$ & ...- & $\begin{array}{c}.025 \\
(1.362)\end{array}$ & $\begin{array}{c}-35.29 \\
(-2.047)\end{array}$ & $\begin{array}{c}25.79 \\
(1.542) \\
\end{array}$ & .171 & 2.487 \\
\hline$\# 5$ & -19.755 & $\begin{array}{c}.643 \\
(2.503)\end{array}$ & $\cdots$ & -.- & $\begin{array}{c}.023 \\
(1.274)\end{array}$ & $\begin{array}{c}-36.77 \\
(-2.132)\end{array}$ & $\begin{array}{l}25.054 \\
(1.494)\end{array}$ & $\begin{array}{l}.166 \\
-\end{array}$ & $\begin{array}{c}2.793 \\
\ldots \\
\end{array}$ \\
\hline
\end{tabular}

As is apparent from Equation \#3 in Table 3, the growth of revenue has a positive effect on the growth of executive compensation. The coefficients of this variable are statistically significantly different from zero. The growth of 
net income also contributes to CEO compensation growth but this effect seems to be weak as judged on the basis of t-statistics. This finding is as expected and consistent with previous findings, as discussed earlier in this paper.

Regarding the human capital hypothesis, the effect of formal education on CEO compensation growth was tested by creating a dummy variable to represent bachelor's and master's degrees in arts, science, law, engineering and business. There were 14 categories of the education altogether. Hence, 13 dummy variables were created. Only law and engineering education appeared to have effects on the growth of CEO compensation. Dummy3 refers to law degree (L.L.B.) and Dummy6 to engineering degree (M.E.). A law background had a negative and an engineering background a positive effect on the growth of CEO compensation. It is possible that CEOs with engineering background are in more demand than others and hence worthy of a higher rate of compensation growth. Or, alternatively CEOs with law background might go for more deferred compensation such as options while accepting lower current cash compensation. It is not possible to disentangle this issue in this paper given the information at hand. Nonetheless, while the effect of formal education has been included in the model, other human capital attributes of CEOs such as work experience and tenure in the office have not been included. Future studies should redress this deficiency. 
As the empirical results in Table 3 show, the percentage of shares owned by CEO (one of the measures of hegemonic power, HP1) did not have any influence on the growth of CEO compensation. However, the percentage of shares under option eligibility revealed a positive but rather weak influence on the growth of CEO compensation. One interpretation of this result may be that CEOs with more unexercised options may try to offset for lower than expected growth in share price by asking for a higher rate of growth in compensation. On the contrary, if share prices grow at more than expected rate, then CEOs may exercise their options. CEOs might not ask for a higher rate of compensation growth in this situation as a significant gain in total compensation can lead to public outcry. The empirical findings thus provide a limited support for the hegemonic power hypothesis. 


\section{CONCLUSIONS}

The main objective of this study was to shed some new light on the determinants of CEO compensation. To that end, I develop a hypothesis called the hegemonic power hypothesis drawing on insights from the field of international relations. I also constructed an index of CEOs' hegemonic power for testing this hypothesis empirically. I then tested the hypothesis but found only a limited support for the hegemonic power hypothesis. While a small sample used in this study may be one of the reasons for this limiting result, there is a sound reason for further refining this hypothesis conceptually and testing it empirically using a larger sample size. In addition, other measures of hegemonic power can be constructed and used in empirical analysis. In any case, I believe this study has attempted to make a small contribution to the growing body of literature on CEO compensation by bringing in a new cross-disciplinary perspective. 


\section{REFERENCES}

Agarwal, Naresh C. 1981. "Determinants of Executive Compensation." Industrial Relations, 20: 36-46.

Baumol, William J. 1959. Business Behavior, Value and Growth. New York: Macmillan.

Bloom, Matthew C., and George T. Milkovich. 1996. "Issues in Managerial Compensation Research." In C.L. Cooper and D.M. Rousseau. (eds.), Trends in_Organizational Behavior, 3.

Buhler, Patricia. 1994. "Navigating the Waters of Organizational Politics." Supervision, 24-26.

Chernoff, Joel. 1995. "Managers Unwillingly Caught in Pay Dispute." Pensions and Investments, 18.

Ciscel, David H., and Thomas M. Carroll. 1980. The Determinants of Executive Salaries: An Econometric Survey. Review of Economics and Statistics, 7-13.

Deckop, John R. 1988. Determinants of Chief Officer Compensation. Industrial and Labor Relations Review, 41: 215-226.

Ehrenberg, Ronald G., and George T. Milkovich. 1988. "Compensation and Firm Performance." In M. Kleiner et al. (eds.), Human Resources and the Performance of the Firm: IRRA Research.

Fama, Eugene F. 1980. "Agency Problems and the Theory of the Firm." Journal of Political Economy, 88: 288-307.

Gomez-Mejia, Luis, Henry Tosi, and Timothy Hinkin. 1987. "Managerial Control, Performance, and Executive Compensation." Academy of Management Journal, 30: 51-70.

Greenbury, Sir. Richard., et al. 1995. "Who Lets Pay Run Away?" Management Today, 36-40.

Griffiths, Martin. 1992. Realism, Idealism and International Politics. London: Routledge. 
Grossman, Wayne.1995. "Does Incentive Compensation Lower Executives Willingness to take Risks?" Academy of Management Executive,9: 91-92.

Hill, C.W., Hitt, M.A., and R.E. Hoskisson. 1992. "Cooperative Versus Competitive Structures in Related and Unrelated Diversified Firms." Organization Science, 3: 501-521.

Hogan, T.D., and D. McPheters. 1980. "Executive Compensation: Performance versus Personal Characteristics." Southern Economic Journal, 46: $1060-1068$.

Hollis, Martin and Steve Smith. 1990. Explaining and Understanding International Relations. Oxford: Clarendon Press.

Kanungo, Rabindra N., and Manuel Mendonca. 1997. Compensation: Effective Reward_Management (2nd edition). Toronto: John Wiley and Sons Canada, Limited.

Keohane, Robert O. and Joseph S. Nye. 1989. Power and Interdependence. Cambridge: HarperCollinsPublishers.

Kim, Ken I., et al. 1990. "Reward Allocations in the United States, Japan, and Korea: A Comparison of Individualistic and Collectivistic Cultures." Academy of Management Journal, 33: 188-198.

Kochan, T.A., and Osterman, P. 1994. The Mutual Gains Enterprise: Forging a Winning Partnership among Labor, Management, and Government. Boston: Harvard Business School Press.

Lawless, Michael W. and Luis R. Gomez-Mejia. 1995. "Strategic Management in high Technology Firms." Monographs in Organizational Behaviour and Industrial Relations, 35: 93-96.

Lazear, Edward, and Sherwin Rosen. 1981. "Rank-Order Tournaments as Optimum Labor Contracts." Journal of Political Economy, 89: 841-864.

Lewellen, Wilbur G. and Blain Huntsman. 1970. "Managerial Pay and Corporate Performance." American Economic Review, LX: 710-720.

Masson, Robert T. 1971. "Executive Motivations, Earnings, and Consequent Equity Performances." The Journal of Political Economy, 79: 1278-1292. 
Milkovich, G.T., and J.M. Newman. 1996. Compensation (5th edn.) Homewood, $\Pi$.: Irwin.

Miller, Daniel J. 1995. "CEO Salary Increases May Be Rational After All: Referents and Contracts in CEO Pay." Academy of Management Journal,38: 1361-1385.

O’Reilly III, Charles A., et al. 1988. "CEO Compensation as Tournament and Social Comparison: A Tale of Two Theories." Administrative Science Quarterly, 33: 257-274.

Roberts, David R. 1959. Executive Compensation. Glencoe, III: Free Press.

Scott, Thomas W. and Peter Tiessen. 1995. "Paying the boss--and how." CA Magazine, 35-38.

Simon, Herbert A. 1957. "Compensation of Executives." Sociometry, 20: 3235 .

Stolley, R. 1987. "How to fire the CEO." Fortune, 116: 38-48.

Stroh, Linda K., et al. 1996. "Agency Theory and Variable Pay Compensation Strategies." Academy of Management Journal, 39: 751-767.

Tosi, Henry L. and Steve Werner. (?). Managerial Discretion and the Design of Compensation Strategy.

Tosi, Henry L. and Luis R. Gomez-Mejia. 1989. "The Decoupling of CEO Pay and Performance: An Agency Theory Perspective." Administrative Science Quarterly, 34: 169-189.

Tosi, Henry L. and Luis R. Gomez-Mejia. 1994. "CEO Compensation Monitoring and Firm Performance." Academy of Management Journal, 37: p. $1002-1016$.

Waltz, Kenneth N. 1979. Theory of International Politics. New York: McGraw-Hill, Inc.

Westphal, James D. and Edward J. Zajac. 1994. "Substance and Symbolism in CEOs Long-term Incentive Plans." Administrative Science Quarterly,39: 367-390. 
Zajac, Edward J. and James D. Westphal. 1995. "Accounting for the Explanations of CEO Compensation: Substance and Symbolism." Administrative Science Quarterly, 40: 283-308. 